\title{
DME AS A FUEL FOR SI ENGINES CARS
}

\author{
Pawel FABIŚ \\ Silesian University of Technology, Faculty of Transport and Aviation Engineering \\ pawel.fabis@polsl.pl
}

\begin{abstract}
The article presents an analysis of the possibility of using DME fuel to power internal combustion engines. The possibilities of using DME as an engine fuel in relation to world and European achievements have been widely discussed. Moreover, the preliminary results of the tests determining the possibility of using the DMELPG mixture to power the diesel engine are presented. The research consisted in determining the influence of the DME-LPG mixture on the power and torque of the engine at various loads. The changes in the temperature of the exhaust gases were also determined in relation to the different proportions of DME in the mixture.
\end{abstract}

Keywords: DME, engine power, engine torque, gaseous fuels, gaseous fuels mixtures

\section{DME JAKO PALIWO DO ZASILANIA POJAZDÓW Z SILNIKAMI ZI}

\section{Streszczenie}

W artykule przedstawiono analizę możliwości zastosowania paliwa DME do zasilania silników spalinowych. Przeprowadzono szerokie omówienie możliwości zastosowania DME jako paliwa silnikowego w odniesieniu do osiągnięć światowych i europejskich. Ponadto przedstawiono wstępne wyniki badań określających możliwość zastosowania mieszaniny DME - LPG do zasilania silnika ZI. Badania polegały na określeniu wpływu mieszaniny DME - LPG na moc i moment obrotowy silnika przy różnych jego obciążeniach. Określono także zmiany temperatury gazów wylotowych w odniesieniu do różnych udziałów DME w mieszaninie.

Słowa kluczowe: DME, moc silnika, moment obrotowy silnika paliwa gazowe, mieszaniny paliw gazowych

\section{INTRODUCTION}

A number of activities undertaken around the world in the last two decades, the objectives of which are primarily related to ensuring energy security and properly understood environmental protection for future generations, include work on technologies for the effective production and combustion of fuels from natural gas, biomass and coal.

The replacement of petroleum-derived fuels with any alternative fuel requires an in-depth and reliable analysis that should assess its compliance with certain important criteria. Comparing several fuels that can replace these petroleum derivatives (methanol, ethanol or fuels produced by the FisherTropsch method), dimethyl ether - DME seems to be the one that has the best chance of becoming popular.

\subsection{Fuel usage criteria}

In the 90s, due to the very low interest in alternative fuels, only the following criteria were used to assess their suitability for driving vehicles: emission of toxic components, $\mathrm{CO}_{2}$ emission, density of energy stored on the vehicle, cost of additional adaptation of the vehicle or its engine, fuel cost and costs related to the construction of infrastructure $[1,13]$. These criteria were sufficient for the proper conduct of many implementation works, including the use of gaseous fuels, in particular natural gas and a mixture of petroleumderived gases to drive motor vehicles. Taking into account the current state of knowledge about the types of manufacturing technology and social expectations, the criteria have been extended and are as follows [3]:

- availability,

- economic,

- environment impact,

- aceptations,

- energetic safety,

- technological criteria,

- universal.

Our expectations towards alternative fuel should not differ significantly from the possibilities provided by the currently used petroleum fuels. DME meets most of the important criteria, which, taking into account: the versatility of its use (heating, cooking, electricity generation, engine fuel) and the availability of cheap and simple technologies for its production, also from waste, makes this energy carrier competitive for conventional fuels. 


\subsection{Fuels properties}

Currently used engine fuels are a mixture of hydrocarbons with a very wide range of boiling points and burning rates. Table 2 compares conventional and alternative fuels, taking into account their boiling point and the likely direction of their conversion. Low boiling point fuels are methane and petroleum gas mixtures used to power diesel engines. These fuels correspond to two other fuels with similar volatility, ie hydrogen and dimethyl ether (DME). DME has a boiling point corresponding to a mixture of petroleum gases, and its high cetane number allows it to be used to power CI engines [9].

Gasoline, kerosene and diesel oil are the most common fuels, which under normal conditions are liquids with high energy condensation - approx. 40 $\mathrm{MJ} / \mathrm{kg}$. In the case of other fuels, their state of aggregation and energy density are very different, therefore in Table 1 they were compared with conventional fuels, selecting their most important properties.

Table 1. Comparison of physicochemical properties of selected fuels [1]

\begin{tabular}{|c|c|c|c|c|c|}
\hline Parameter & Methan & Methanol & $\begin{array}{l}\text { Dimethylo } \\
\text { ether } \\
\text { (DME) }\end{array}$ & Petrol & Diesel \\
\hline Sign & $\mathrm{CH}_{4}$ & $\mathrm{CH}_{3} \mathrm{OH}$ & $\mathrm{CH}_{3} \mathrm{OCH}_{3}$ & $\mathrm{C}_{7} \mathrm{H}_{16}$ & $\mathrm{C}_{14} \mathrm{H}_{30}$ \\
\hline $\begin{array}{l}\text { Molecular } \\
\text { weight } \\
{[\mathrm{g} / \mathrm{mol}]}\end{array}$ & 16,4 & 32,04 & 46,07 & 100,2 & 198,4 \\
\hline $\begin{array}{l}\text { Density } \\
{\left[\mathrm{g} / \mathrm{cm}^{3}\right]}\end{array}$ & 0,720 & 0,792 & $\begin{array}{c}\mathbf{0 , 6 6 1} \\
\text { (liquid) } \\
\mathbf{2 , 0 5 7} \\
\text { (vapored) }\end{array}$ & 0,737 & 0,856 \\
\hline $\begin{array}{c}\text { Boiling } \\
\text { temperature } \\
{\left[{ }^{\circ} \mathrm{C}\right]}\end{array}$ & -162 & 64 & $-24,9$ & $17-220$ & $140-380$ \\
\hline $\begin{array}{l}\text { Octane } \\
\text { number }\end{array}$ & 130 & 104 & - & $80-100$ & - \\
\hline $\begin{array}{l}\text { Cetane } \\
\text { number }\end{array}$ & - & - & $55-60$ & - & $40-55$ \\
\hline $\begin{array}{l}\text { Low } \\
\text { calorific } \\
\text { value } \\
\quad[\mathrm{MJ} / \mathrm{kg}]\end{array}$ & 50,2 & 20,1 & 28,8 & 43,47 & 41,66 \\
\hline $\begin{array}{c}\text { Air/Fuel } \\
{[\mathrm{kg} / \mathrm{kg}]}\end{array}$ & 17,2 & 6,45 & 9,0 & 14,7 & 14,6 \\
\hline $\begin{array}{c}\text { Ignition } \\
\text { temperature } \\
{\left[{ }^{\circ} \mathrm{C}\right]}\end{array}$ & $540-650$ & 385 & 350 & $228-300$ & $150-250$ \\
\hline $\begin{array}{l}\text { Burn } \\
\text { velocity } \\
{[\mathrm{cm} / \mathrm{s}]}\end{array}$ & $30-33,8$ & 52 & $42,9-61$ & $30-60$ & \\
\hline $\begin{array}{c}\text { Coal } \\
{[\%]}\end{array}$ & 74 & 37,5 & 52,2 & 85,5 & 87 \\
\hline $\begin{array}{c}\text { Sulfur } \\
{[\mathrm{ppm}]}\end{array}$ & $7-25$ & 0 & 0 & $\sim 200$ & $\sim 250$ \\
\hline
\end{tabular}

Dimethyl ether (DME) highlighted in the table is an ether of the simplest chemical formula, and its physicochemical properties are similar to those of petroleum gases, propane and butane. It is a volatile organic compound, but is not carcinogenic, teratogenic or mutagenic. Its decomposition time in the troposphere is 5.1 days, and the global warming impact index is 1.2 years (in a twenty-year perspective), 0.3 (in a hundred-year perspective) and 0.1 years (in a 500-year perspective) [8,9]. It can therefore be concluded that the impact of DME is neutral to the environment.

\subsection{Producing and distribution of the DME}

Dimethyl ether is produced in a two-phase technological process. In the first stage, synthetic gas is converted into methanol, and in the second, dimethyl ether is obtained by dehydrating methanol.

Since raw materials such as natural gas, coal and biomass can be used to produce synthetic gas, there are no restrictions on the sources of DME. Technological processes for the production of DME, based on autothermal reactors and direct synthesis, are currently the subject of many development works, and the obtained results are almost immediately commercialized. The costs (Table 2) of DME production depend mainly on the cost of the input raw material for production and the efficiency of the technological line.

Table 2. Costs producing of the fuels

\begin{tabular}{|l|c|c|c|c|}
\hline Jednostka & $\begin{array}{l}\text { Natural } \\
\text { gas }\end{array}$ & Petrol $^{\mathrm{a}}$ & Diesel oil & $\mathrm{DME}^{\mathrm{b}}$ \\
\hline $\begin{array}{l}\text { USD for GJ } \\
\text { thru LHV }\end{array}$ & $4-7$ & $6-12$ & $6-12$ & $5-14$ \\
\hline
\end{tabular}

a average at 2002-2005 [6]

$\mathrm{b}$ average price with the capacity of technological lines from 2,500 to 5,000 t / day, transport over a distance not exceeding $6,000 \mathrm{~km}$, with the purchase costs of natural gas 1,5 USD/GJ [6]

The Japanese NKR corporation, which produces DME using direct natural gas synthesis, reports that with a purchase price of natural gas of USD 1.42 per GJ and transport costs for a distance not exceeding $6,000 \mathrm{~km}$ for a production line with a capacity of approx. 5,000 t / day, the cost of DME is $\$ 5.45$ / GJ. An approximate comparison of the production costs of selected fuels is presented in the table 2 .

Since methanol, and consequently also DME, are not natural resources, their prices are directly related to the price of the raw material used to produce them. The dynamically developing technologies of obtaining DME from other sources, in particular from biomass (BioDME) and plastic waste, affect the stability of the fuel price, making it independent of the impact of changes in natural gas prices.

\subsection{DME as a engine fuel}

Assessing the suitability of DME as an engine fuel, it has been shown that it is perfectly suited for diesel engines. It burns soot-free, has a low flash point, and also evaporates perfectly. These advantages, confirmed by the results of many research works, are the result of the lack of direct bonding of carbon in the atomic structure, as well as the presence of oxygen in this bond (approx. 35\% by mass). A properly optimized DME combustion process management system also significantly reduces $\mathrm{NO}_{\mathrm{x}}$ emissions $[13,14]$. As an additive to other fuels, DME can also increase their flammability range, and its mixtures can be used in 
dual-fuel diesel engines, HCCI, CCCI engines, as well as in SI engines.

The properties of DME in comparison with a mixture of propane and butane are similar, differing only in the calorific value and the octane number. The calorific value of DME is approx. $63 \%$ of the calorific value of butane, which means that the engine must receive twice as much fuel in the cycle to develop the same power.

Increased interest in DME as an engine fuel took place in Europe in the 1990s, after the development of cheap and simple technologies for its mass production. With a delay of several years, work on its use for vehicle propulsion began in Japan, and then in China and South Korea. The results of research projects carried out in this period laid the foundations for the implementation and development of prototype trucks and buses powered by this fuel. In 1998, the Japanese company Nippon Kokan, as part of a project financed by the Ministry of Infrastructure and Transport, began operational testing of a truck and a year later of a DME powered bus. Today in Japan, trucks and buses are also manufactured by companies such as Nissan Diesel, Hindo Motors, Isuzu and Mitsubishi Motors.

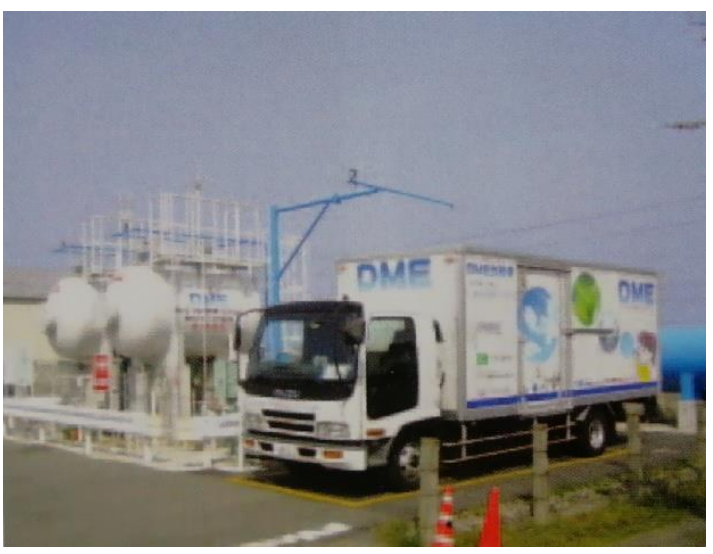

Fig. 1. Heavy duty car at the DME filling stations (North Korea) [8]

In Europe, only Volvo Truck Corporation showed interest in this fuel by launching a DME implementation project for the drive of trucks. Currently, a very advanced project is carried out by a consortium formed by several companies (Volvo Truck Corporation, Chemrec, Delphi, Haldor Topsøe, ETC, Preem, Total) and it is financed by the EU's Seventh Framework Program, the Swedish Energy Agency and the participating companies. For this project, Bio-DME is produced from a black liquor, a semi-liquid, high-energy by-product of the pulp industry.

When considering the use of DME as a fuel for propelling vehicles, engineers and vehicle designers faced the need to overcome a number of technical barriers based on the physicochemical properties of this fuel. These barriers set the main directions of research, which contributed to the introduction and dissemination of innovative design solutions. The most important interrelationships between the properties of DME and the requirements ensuring efficient conversion of the energy contained in the fuel.

Two combustion systems are currently used in diesel engines - the first, using a mixture of air and DME prepared in the engine's intake manifold, and the second, where DME is injected directly into the combustion chamber. Both systems can be used in single or multi-fuel systems. Depending on the combustion system used, not only different strategies for controlling the combustion process are implemented, but also different devices and elements of the power supply system are used.

Since DME is a gas that becomes liquid at a pressure of just 5 bar, it is stored in the vehicle just like LPG. Also, other elements and devices of the power supply system only slightly differ from those used in LPG vehicles.

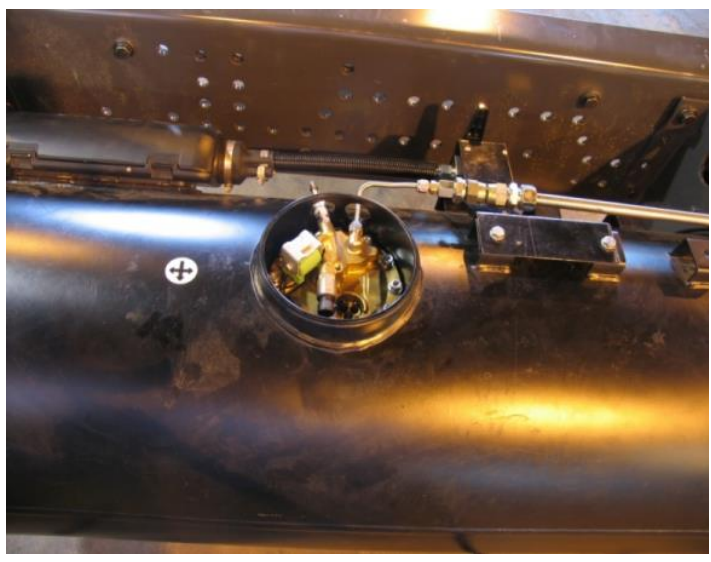

Fig. 2. Automotive DME container at the heavy duty frame car

The diesel fueling systems DME are pressurized systems that keep this fuel in the liquid phase. DME is also injected into the combustion chambers of the engine in the liquid phase, in an amount sufficient to obtain the required amount of energy (Fig. 2). The DME injection pressures are very low compared to diesel fuel, ranging from 19 to $25 \mathrm{MPa}$ (in the case of diesel fuel from 40 to $140 \mathrm{MPa}$ ). Low injection pressure together with optimally selected DME dosing strategies contribute to the fact that a modern DME powered engine has parameters that are comparable to a diesel engine, with significantly lower emissions of toxic components in the exhaust gas and lower production costs of the power system.

The operational tests carried out so far have shown that the emission of controlled exhaust gas components is much lower for the DME powered engine. The comparison of diesel and DME emissions with the requirements of the Japanese standard for an engine with a displacement of 7.1 $\mathrm{dm} 3$ is shown in the table 3 . 
Table. 3. The results of the measurement of the emission of toxic components for the engine [g/kWh] [5]

\begin{tabular}{|lc|c|c|c|c|}
\hline & CO & HC & NO $_{\mathbf{x}}$ & PM \\
\hline $\begin{array}{l}\text { Japanese Diesel } \\
\text { mode standard }\end{array}$ & 2,22 & 0,87 & 3,38 & 0,18 \\
\hline Diesel & 3,17 & 0,89 & 4,26 & 0,17 \\
\hline DME & 0,117 & 0,222 & 2,479 & 0,0102 \\
\hline $\begin{array}{l}\text { Comparison of the } \\
\text { norm and DME }\end{array}$ & $\mathbf{- 9 5 \%}$ & $\mathbf{- 7 4 \%}$ & $\mathbf{- 2 7 \%}$ & $\mathbf{- 9 4 \%}$ \\
\hline
\end{tabular}

$\mathrm{CO}_{2}$ emission from one kilogram of fuel for DME is about $10 \%$ lower compared to diesel fuel and results from the more favorable $\mathrm{H} / \mathrm{C}$ ratio for DME. The results of operational tests of DME powered vehicles obtained so far allow to determine the significant advantages and disadvantages of DME as an engine fuel. Advantages of the DME:

- compared to other alternative fuels, mainly natural gas and hydrogen, storing DME on the vehicle, filling the tanks and transporting this fuel is much easier, as is LPG.

- greater combustion efficiency can be achieved as the ignitability of DME is more favorable than that of diesel fuel.

- the combustion of DME is not associated with smoke, as it does not directly bond C-C.

- the combustion of DME does not produce $\mathrm{SO}_{\mathrm{x}}$ as this fuel does not contain sulfur.

- the absence of $\mathrm{SO}_{x}$ and smoke facilitates the selection of catalyst materials in exhaust gas treatment systems.

- the photochemical reactivity of the exhaust gases is low, thus there is no risk of producing groundlevel ozone.

- in the process of fuel preparation, refueling, as well as in maintenance and repair works, there are no hazards that could adversely affect human health.

Disadvantages of the DME:

- the calorific value of DME is half that of diesel, which doubles the amount of fuel delivered to the engine, and consequently also increases the capacity of the fuel storage tanks on the vehicle. At the same time, it prevents the direct use of this fuel to power vehicles already in operation with diesel engines.

- the wear of the moving parts of the fuel system increases due to the lower viscosity of the fuel and its worse lubricating properties.

- damage to sealing materials, mixtures of natural and synthetic rubber, adhesives and resins is possible.

- ease of evaporation of DME due to the low boiling point, requires the use of a small number of connections and proper sealing of elements and devices of the supply system.

- low octane number prevents DME from being used to power IG motors. However, for these units it is possible to use $\mathrm{LPG}+\mathrm{DME}$ mixtures with a mass fraction of DME not exceeding $30 \%$.

It is also necessary to conduct further tests for engines fueled with DME - LPG mixtures. The test results will allow to determine the environmental impact of powered engines and energy consumption of a vehicle powered by such a mixture.

\section{RESEARCH OBJECTS AND MEASUREMENTS SET-UP}

Due to the need to use DME as an LPG additive, the problem arises as to how to enrich LPG. DME additive applications can be carried out, e.g. at the LPG bottling plant stage, where it is possible to load the right amount of DME during loading or just before loading. It is also possible to make a mixing system, the initial installation of which was carried out at the Faculty of Transport and Aeronautical Engineering of the Silesian University of Technology.

Using the apparatus presented, tests were carried out on the impact of DME admixtures on the dynamic parameters of the engine. Thanks to this research, it was possible to assess the efficiency of LPG and DME fuel mixture combustion.

In the conducted research, mixtures were used, which were produced using a special stand, gas mixing was carried out in a strictly defined sequence, thus preparing LPG and DME mixtures with the following mass fractions:

- $7 \%$ DME, $93 \%$ LPG,

- $\quad 11 \%$ DME, $89 \%$ LPG,

- $14 \%$ DME, $86 \%$ LPG,

- $\quad 17 \%$ DME, $83 \%$ LPG,

- $21 \%$ DME, $79 \%$ LPG,

- $26 \%$ DME, $74 \%$ LPG,

- $30 \%$ DME, $70 \%$ LPG,

- $100 \%$ LPG (propane - butane mixtures with 40/60).

The mixtures prepared in this way were introduced into a properly configured supply system, which was a system of additional equipment for the tested car (fig. 3). This system delivered the vaporized gas mixture to the inlet channels of the tested engine. The influence of DME share on engine operation was assessed for three loads: $21 \%, 48 \%$ and $100 \%$.

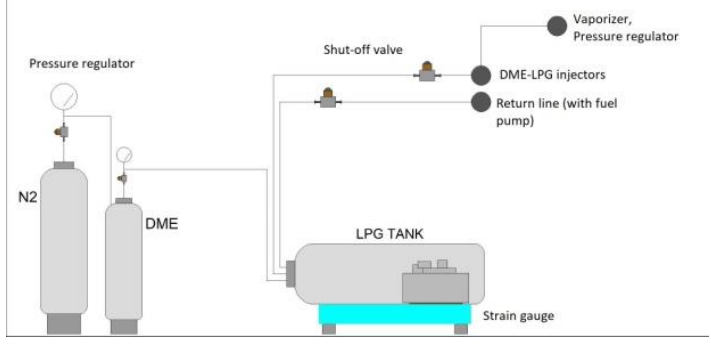

Fig. 3. LPG and DME mixtures stand scheme [10] 
The object of the research was a OPEL ASTRA car powered by a ZI engine with a capacity 1600 $\mathrm{cm}^{3}$, adapted to be powered by an alternative gas fuel. The main data characterizing the engine of the tested car are presented in table 4.

Table 4. Main data of the researched engine

\begin{tabular}{|l|c|}
\hline $\begin{array}{l}\text { Number of } \\
\text { cylinders }\end{array}$ & $4 \mathrm{R}$ \\
\hline Power and RPM & $55 \mathrm{~kW} / 5200 \mathrm{~min}^{-1}$ \\
\hline Torque and RPM & $128 \mathrm{Nm} / 2800 \mathrm{~min}^{-1}$ \\
\hline Capacity & $1598 \mathrm{~cm}^{3}$ \\
\hline Bore & $79.0 \mathrm{~mm}$ \\
\hline Stroke & $81.5 \mathrm{~mm}$ \\
\hline Compresion ratio & 9.6 \\
\hline
\end{tabular}

The operating parameters of the car engine were determined by analyzing its characteristics, which were obtained using a Bosch chassis dynamometer, type FLA 203, for previously prepared mixtures with a different mass fraction of DME. A simplified diagram of the stand is shown in Fig. 4.

The test stand was equipped with transducers and sensors ensuring identification of the engine operating state. Basic control and measurement systems, ensuring continuous recording of the engine operation status, were, among others, measuring devices:

- in-cylinder pressure,

- crank angle with TDC,

- wheel power,

- intake maniforld pressure,

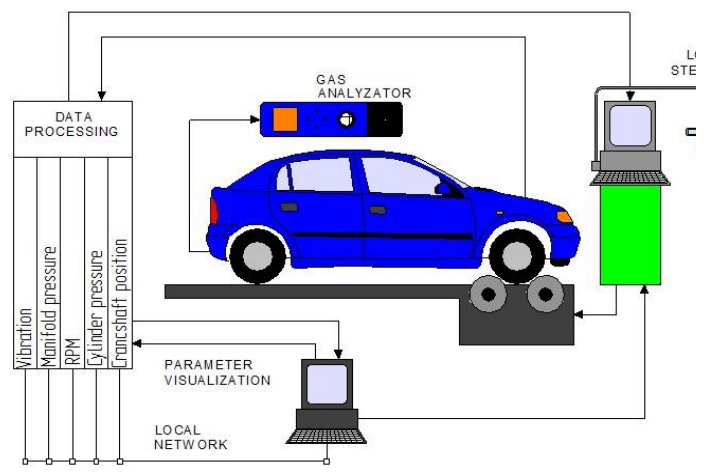

Fig. 4. Scheme of testing stand [10]

- inlet air and gas exhaust temperature,

- gaseous fuel mass flow delivered to the engine.

The in-cylinder pressure was measured using a piezoelectric pressure sensor type 6121 connected to 5011 charge amplifier from KISTLER. The position of the crankshaft and its RPM were determined using the KISTLER 2613B crankshaft position marker.

Additionally, the signal from the absolute pressure transducer in the engine intake manifold was measured and recorded. The transducer is an integral part of the gasoline fuel injected to the intake manifold of the tested car's engine. The mass flow of gaseous fuel flowing into the engine supply system was measured with a precise strain gauge. All measured parameters were recorded and visualized using the NI PCI-6143 data acquisition card and a proprietary program developed in the environment LabView 7.1

\section{RESULTS AND DISCUSSION}

For the above-mentioned gas fuel mixtures, the engine power and torque were measured. Measurements were carried out for three assumed engine loads: $100 \%, 48 \%$ and $21 \%$. The measurement results are presented in the table 5 .

Table 5. Results of the dyno measurement

\begin{tabular}{|c|c|c|c|c|c|c|}
\hline \multirow{3}{*}{ Fuel } & \multicolumn{6}{|c|}{ Engine load [\%] } \\
\hline & \multicolumn{2}{|c|}{$100 \%$} & \multicolumn{2}{|c|}{$48 \%$} & \multicolumn{2}{|c|}{$21 \%$} \\
\hline & $\begin{array}{c}\text { Power } \\
{[\mathrm{kW}]}\end{array}$ & $\begin{array}{c}\text { Torque } \\
{[\mathrm{Nm}]}\end{array}$ & $\begin{array}{l}\text { Power } \\
{[\mathrm{kW}]}\end{array}$ & $\begin{array}{c}\text { Torque } \\
{[\mathrm{Nm}]}\end{array}$ & $\begin{array}{l}\text { Power } \\
{[\mathrm{kW}]}\end{array}$ & $\begin{array}{c}\text { Torque } \\
{[\mathrm{Nm}]}\end{array}$ \\
\hline $\begin{array}{c}7 \% \\
\text { DME, } \\
93 \% \\
\text { LPG }\end{array}$ & 57,6 & 129,6 & 43,3 & 122,0 & 17,9 & 89,2 \\
\hline $\begin{array}{c}11 \% \\
\text { DME, } \\
89 \% \\
\text { LPG }\end{array}$ & 57,2 & 126,3 & 43,6 & 119,1 & 15,6 & 81,8 \\
\hline $\begin{array}{c}14 \% \\
\text { DME, } \\
86 \% \\
\text { LPG }\end{array}$ & 55,1 & 126,3 & 49,0 & 125,3 & 18,8 & 93,5 \\
\hline $\begin{array}{c}17 \% \\
\text { DME, } \\
83 \% \\
\text { LPG }\end{array}$ & 57,0 & 129,6 & 47,8 & 126,6 & 24,0 & 103,0 \\
\hline $\begin{array}{c}21 \% \\
\text { DME, } \\
79 \% \\
\text { LPG }\end{array}$ & 58,3 & 131,1 & 48,3 & 125,8 & 21,4 & 98,4 \\
\hline $\begin{array}{c}26 \% \\
\text { DME, } \\
74 \% \\
\text { LPG }\end{array}$ & 58,6 & 124,6 & 44,2 & 119,8 & 23,1 & 97,8 \\
\hline $\begin{array}{c}30 \% \\
\text { DME, } \\
70 \% \\
\text { LPG }\end{array}$ & 56,8 & 120,6 & 43,9 & 116,2 & 24,9 & 94,0 \\
\hline $\begin{array}{l}100 \% \\
\text { LPG }\end{array}$ & 56,5 & 129,1 & 49,5 & 123,4 & 25,6 & 104,3 \\
\hline
\end{tabular}

The presented results clearly show that there is a clear change in the dynamic parameters of the engine. The maximum power and torque values are reduced compared to the reference value (pure LPG) only for higher DME contents (above 26\%). At full engine load (100\%), for LPG fuel enriched with 7\%, $11 \%, 17 \%, 21 \%$ and $26 \%$ DME content, the torque value increased and the engine power was maintained at a comparable value. In the case of partial loads ( $48 \%$ and $21 \%$ ), the maximum power and torque values are lower (than LPG fuel) for all DME shares in the mixture. However, for the $14 \%$, $17 \%$ and $21 \%$ DME shares, the power values are close to the power values corresponding to the base fuel (LPG).

Dynamometer charts with power and torque waveforms are presented in Figures 5, 6 and 7. 


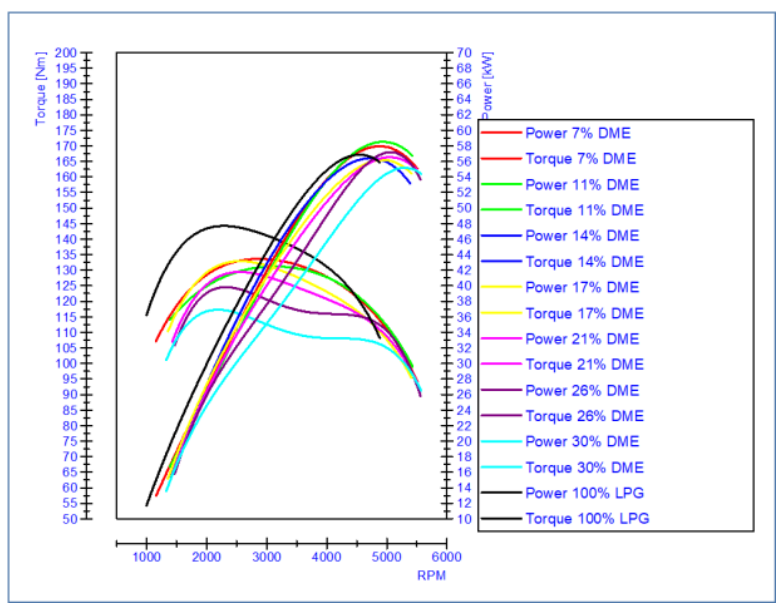

Fig. 5. Gas exhaust temperature for different DME blends and $100 \%$ loads

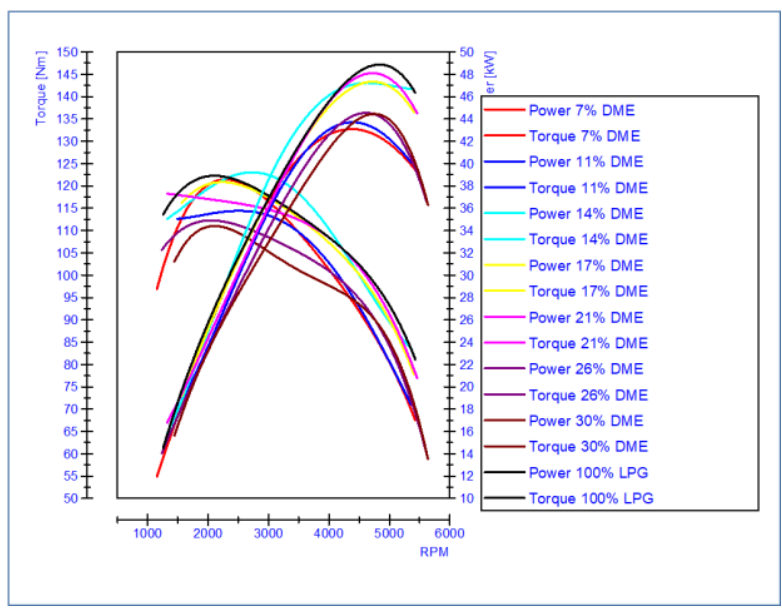

Fig. 6. Gas exhaust temperature for different DME blends and $48 \%$ loads

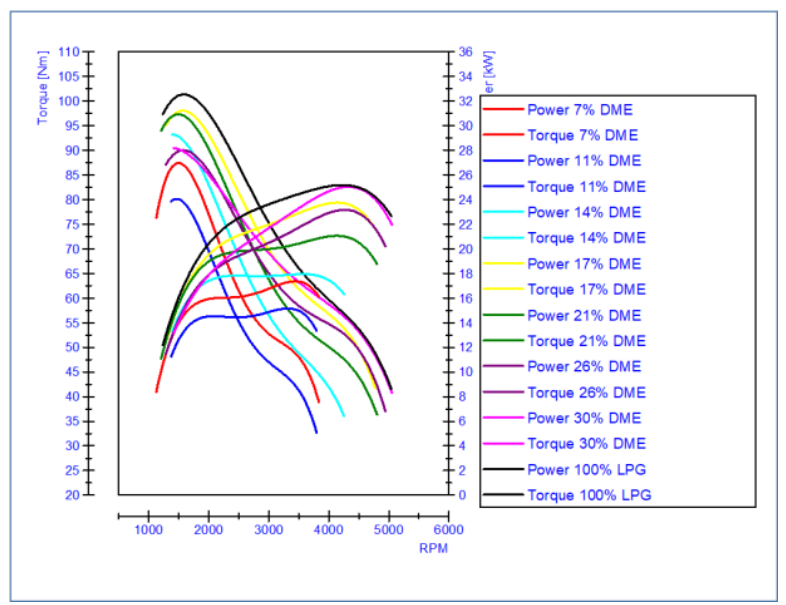

Fig. 7. Gas exhaust temperature for different DME blends and $21 \%$ loads

The assessment of the possibility of using DME - LPG mixtures to SI engines was based on the measurements and analysis of exhaust gas temperatures. The graph in Figure 8 shows that the highest temperature ranges are recorded for DME shares of $17 \%$ and $21 \%$. The lowest temperatures, in turn, are recorded with a share of $7 \%$ to $14 \%$. As the share of DME increases $(>21 \%)$, the temperature of the exhaust gases begins to decrease, but does not reach the levels recorded for the range $7-14 \%$.

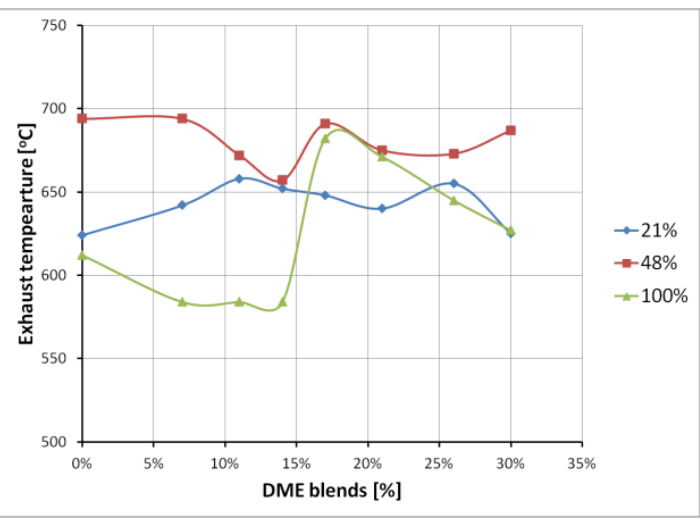

Fig. 8. Gas exhaust temperature for different DME blends and different loads

With regard to LPG fuel, DME - LPG mixtures record different values. The temperature of exhaust gases when fueling the engine with LPG fuel was about $612-694{ }^{\circ} \mathrm{C}$. Mixtures with a share of $7-14 \%$ DME show a similar temperature range regardless of speed rotating crankshaft.

In the case of mixtures with a share of $17-30 \%$ DME, the temperatures of the exhaust gases are higher than for the base fuel (LPG) and range from $625-691{ }^{\circ} \mathrm{C}$. Large fluctuations in exhaust gas temperature are visible at $100 \%$ load. At partial loads (21\% and $48 \%$ ), the temperature fluctuations are significantly smaller.

\section{CONCLUSIONS}

According to the European Union, by 2030 BioDME can replace diesel oil in road transport in more than $50 \%$ of vehicles powered by diesel engines (EUCAR / CONCAWE / JRC 2005, European Commission). The dynamic development of DME production technology as a fuel for motor vehicles takes place in many countries of the world. In 2005, a Russian-Turkish consortium was established, which started work on the development of cheap DME production technologies, mainly from natural gas. In China, several lines for the production of DME from coal and methanol have been put into operation since 2000. The DME produced in this way is mixed with LPG and is used primarily in households and for fueling diesel engines. The country has also developed a network of DME vehicle tank filling stations, which enables the operation of approx. 1.000 buses. In Japan, a consortium whose shareholder is incl. Total oil concern has launched two large DME production plants, while vehicle manufacturers have delivery trucks, trucks and buses proven in many years of 
operation. Moreover, interest in this fuel, visible in the recently launched investments, is also observed in Korea, Iran and Egypt. Projects related to the use of DME as motor fuel are also carried out in Canada and the United States. It can therefore be assumed that the worldwide investments in technological lines for the production of DME will foster greater interest in its use as an engine fuel. In addition, the development of DME production technology will not be limited only to obtaining it from fossil resources (coal, natural gas), but also biomass will be the starting material for production (as in the case of Scandinavia).

The conducted research allowed to determine the influence of the DME admixture content on the dynamics parameters of the internal combustion engine, i.e. power and torque. The power and torque values obtained from the tests for the adopted types of fuels allow to determine that increasing the DME addition above $17 \%$ in LPG gas fuel reduces the power and torque.

Based on the tests carried out on various mixtures, it seems that the mixtures with the most favorable DME bland are fuels with the content of 14 to $21 \%$. These fuels allow to achieve the most favorable results of the engine output parameters (power and torque). Mixtures with a share of $14 \%$ $21 \%$ are characterized by the maximum power values similar to the reference fuel (LPG).

Moreover, it was noticed that it was possible to regulate the combustion process by changing the DME additive content. This phenomenon can be caused by a different duration of the combustion process.

\section{REFERENCES}

1. Flekiewicz M. Gaz ziemny jako paliwo do pojazdów samochodowych. Seminarium N.-T. „Gaz ziemny do pojazdów samochodowych”. Wrocław 2001.

2. Wang MQ, Huang HS. A full fuel-cycle analysis of energy and emission impacts of transportation fuels produced from natural gas. ANI/ESD-40. 2008. https://doi.org/10.2172/750803

3. Sorenson SC. Dimethyl ether in diesel engines: Progress and perspectives. J. Eng. Gas Turbines Power. 2001;123(3):652-658. https://doi.org/10.1115/1.1370373

4. Good DA, Francisco JS, Jain AK, Wuebbles DJ. Lifetimes and global warming potentials for dimethyl ether and for fluorinated ethers: CH3OCF3 (E143a), CHF2OCHF2 (E134), CHF2OCF3 (E125). Atmospheric Chemistry. 1998;03:28181-28186. https://doi.org/10.1029/98JD01880

5. Spath PI, Dayton DC. Preliminary screening-technical and economic assessment of synthesis gas to fuels and chemicals with emphasis on the potential for biomassderived syngas. NREL/TP-510-34929.2003. https://doi.org/10.2172/15006100

6. Namasivayam AM, Korakianitis T, Crookes RJ, BobManule KDH, Olsen J. Biodiesel, emulsified and dimethyl ether as a pilot fuels for natural gas fuelled engines. Applied Energy. 2010;87:769-778. https://doi.org/10.1016/j.apenergy.2009.09.014

7. Kampanart T., Porjade S., Warirat T. Engine performance of dual fuel operation with in-cylinder injected diesel fuels and in-port injected DME. Energy Procedia. 2017;142:461-467. https://doi.org/10.1016/j.egypro.2017.12.072

8. DME Handbook, Japan DME Forum Ohmsha Ltd. Japan, 2006

9. DME Handbook - Supplement, Japan DME Forum Ohmsha Ltd. Japan, 2011.

10. Fabiś P, Flekiewicz M. Ocena dynamiki silnika spalinowego zasilanego mieszaniną LPG i DME. Zeszyty Naukowe Politechniki Śląskiej Seria Transport. 2013: 31-44. https://doi.org/10.20858/sjsutst.1983.1.1

11. Semelsberger TA, Borup RL, Greene HL. Dimethyl ether (DME) as na alternative fuel. Journal of Power Sources. 2006;156:497-511. https://doi.org/10.1016/j.jpowsour.2005.05.082

12. Kwak J.H., Kim H.S., Lee J.H., Lee S.H. On-road chasing measurement of Exhaust particle emissions form diesel, CNG, LPG, and DME-fueled vehicles using a mobile emission laboratory. International Journal of Automotive Technology. 2014;15(4): 543551. https://doi.org/10.1007/s12239-014-0057-z

13. Stepanenko D, Kneba Z. DME as alternative fuel for compression ignition engines - a review. Combustion Engines. 2019:172-179. http://dx.doi.org/10.19206/CE-2019-230

14. Górski W, Jabłońska MM. Eter dimetylowy uniwersalne, ekologiczne paliwo XXI wieku. Nafta Gaz. 2012.

15. Drbal M. A metod of rotary engine performance prediction. Scientific Journal of Silesian University of Technology. Series Transport. 2020;108:37-43. https://doi.org/10.20858/sjsutst.2020.108.4

16. Puškár M, Kopas M, Puškár D. Influence analysis of detonations related to output characteristics and to damage level of engine parts in order to eliminate potential risks and ensure reliability of the HCCI technology. Scientific Journal of Silesian University of Technology. Series Transport. 2019;102:151-163. https://doi.org/10.20858/sjsutst.2019.102.13.

\section{Received 2020-10-05}

Accepted 2021-02-19

Available online 2021-02-24

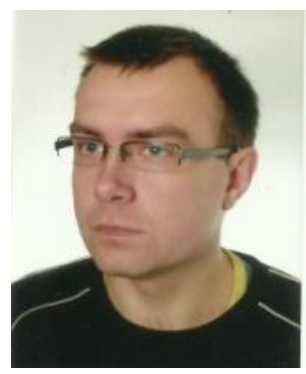

Pawel FABIŚ, received $\mathrm{PhD}$ degree in Faculty of Transport from Silesian University of Technology, Katowice, Poland, in 2007. Field of interest are electromobility problems and internal combustion engine diagnosis. $\mathrm{He}$ is also investigating the possibility of using various gaseous fuels to power internal combustion engines. 